\title{
EKSTRAKSI ANTIOKSIDAN PADA LIDAH BUAYA (Aloe vera) BERBANTU GELOMBANG MIKRO
}

\author{
Maharani Kusumaningrum*, Harianingsih \\ Jurusan Teknik Kimia, Fakultas Teknik, Universitas Wahid Hasyim \\ Jl. Menoreh Tengah X/22 Sampangan, Semarang. \\ Email: maharani@gmail.com
}

\begin{abstract}
Abstrak
Antioksidan sangat diperlukan oleh kesehatan tubuh sebagai penangkal radikal bebas. Banyak penelitian yang mengkaji adanya antioksidan pada beberapa tanaman. Pada penelitian ini dikaji antioksidan yang terdapat pada lidah buaya. Karena lidah buaya dianggap sebagai tanaman yang mudah dikembangbiakkan serta murah, sehingga akan menghasilkan antioksidan dengan biaya bahan baku yang murah. Proses ekstraksi antioksidan dilakukan dengan menggunakan bantuan gelombang mikro dengan pelarut $n$ heksane dan methanol. Hasil penelitian diperoleh bahwa pada proses ekstraksi berbantu gelombang mikro penggunaan pelarut $n$-heksane akan efektif jika ditambahkan pelarut methanol yang lebih polar. Antioksidan dari lidah buaya optimum sebesar 56,29\% pada suhu $50^{\circ} \mathrm{C}$ dan waktu ekstraksi 5 jam. Antioksidan juga akan optimum dihasilkan jika konsentrasi pelarut n-heksan $60 \%$ sebesar $13,78 \%$.
\end{abstract}

Kata kunci : aloe vera, antioksidan, ekstraksi

\section{PENDAHULUAN}

Tanaman lidah buaya merupakan tanaman yang berasal dari Afrika dengan ciri khas mempunyai daging tebal berlendir dan bening, serta sisi daun berduri dan memanjang berwarna hijau. Tanaman ini baru dijadikan sebagai bahan makanan mulai tahun 1900-an (Hernani, 2005).

Beberapa penelitian yang menkaji tentang lidah buaya menemukan bahwa lidah buaya mengandung unsur-unsur antara lain karbohidrat berupa monosakarida dan polisakarida, asam amino baik essensial maupun non essensial, lignin, mineral, saponin, vitamin, dan enzim yang semuanya dapat dimanfaatkan oleh tubuh.. Daging lidah buaya yang berlendir mengandung mineral-mineral antara lain Seng, Kalium, Besi dan vitamin A.

Pada tabel 1 dibawah ini akan disajikan kandungan gizi dari lidah buaya.

Tabel 1. Kandungan gizi lidah buaya

\begin{tabular}{lc}
\hline Zat Gizi & Kandungan / 100 g Bahan \\
\hline Energi (Kal) & 4 \\
Protein (g) & 0.1 \\
Lemak (g) & 0.2 \\
Serat (g) & 0.3 \\
Abu (g) & 0.1 \\
Kalsium (mg) & 85 \\
Fosfor (mg) & 186 \\
Besi (mg) & 0.8 \\
Vitamin C (mg) & 3.476
\end{tabular}

\begin{tabular}{ll} 
Vitamin A (IU) & 4.594 \\
Vitamin B1(mg) & 0.01 \\
Kadar Air (g) & 99.20 \\
\hline
\end{tabular}

Sumber : Departemen Kesehatan R.I., (1992).

Lidah buaya juga mengandung mengandung antioksidan. Antioksidan merupakan zat atau bahan yang dapat menghambat proses terjadinya oksidasi. Antioksidan merupakan molekul yang dapat menetralkan radikal bebas dengan menerima atau memberi electron yang gunanya sebagai eliminator agat electron tidak berpasangan. Fungsi antioksidan untuk melindungi komponen-komponen makanan yang mempunyai ikatan rangkap atau tidak jenuh terutama minyak dan lemak. Antioksidan dapat juga digunakan untuk mengurangi ketengikan.

\section{Ekstraksi dengan Gelombang Mikro}

Ekstraksi menggunakan gelombang mikro merupakan ekstraksi berbantu radiasi gelombang elektromagnetik yang berada pada frekuensi antara $300 \mathrm{MHz}$ sampai $300 \mathrm{GHz}$. Frekuensi tersebut merupakan batas yang diperbolehkan untuk memposisikan gelombang elektromagnetik dalam spectrum diantaranya spectrum FR dan IR (Mandal dkk., 2007). Spektrum gelombang elektromagnetik juga berbanding terbalik dengan panjang gelombang. 
Energi foton radiasi gelombang elektromagnetik berada diantara $1.2 \times 10^{-6}$ hingga $1.2 \times 10^{-3} \mathrm{eV}$ (Mandat dkk., 2007).

Ekstraksi menggunakan microwave berbantu gelombang mikro ini mempunyai prinsip kerja melewatkan radiasi pada bahan yang akan diekstraksi misalnya minyak, lemak, air, gula, ataupun senyawa-senyawa yang terdapat dalam bahan makanan. Pada saat radiasi dialirkan terjadi penyerapan energy yang dikenal dengan pemanasan dielektrik. Molekul pada senyawa yang mempunyai dipol elektrik artinya molekul tersebut memiliki muatan negative pada satu sisi dan tentu saja muatan positif pada sisi yang lain. Muatan ini menyebabkan timbulnya medan elektrik yang diinduksikan melalui gelombang elektromagnetik yang nantinya masing-masing sisi akan berputar kemudian mensejajarkan antara satu dengan yang lain. Gerakan molekul pada senyawa yang diekstraksi akan menimbulkan panas seiring dengan adanya gesekan antar molekul. Energi panas yang ditimbulkan pada peristiwa pemberian radiasi berfungsi sebagai agen pemanasan (mandal dkk., 2007).
Ekstraksi berbantu gelombang mikro dipengaruhi oleh penggunaan pelarut yang tujuannnya menghasilkan ekstrak yang optimal. Pemilihan pelarut berdasarkan kelarutan senyawa dalam pelarut tersebut. Interaksi antara senyawa pelarut dan bagaimana kekuatan pelarut dapat bekerja dalam gelombang elektromagnetik sehingga dapat menyerap energy (Kumoro, 2007). Kemampuan pelarut untuk menyerap energy kemudian mengubahnya men

Tabel 2 menunjukkan bahwa kemampuan etanol dan metanol dalam menyerap energi gelombang elektromagnetik adalah lebih rendah daripada air karena nilai konstanta dielektriknya yang lebih rendajadi panas disebut dengan faktor disipasi. Faktor disipasi dinyatakan sebagai perbandingan antara dielektrik loss atau efisiensi pelarut dalam mengkonversi energy gelombang elektromagnetik menjadi panas dengan konstanta dielektrik yaitu ukuran kemampuan pelarut dalam menyerap energy. Nilai konstanta dielektrik untuk beberapa pelarut dapat dilihat pada tabel 2 .

Tabel 2. Konstanta dielektrik pelarut (Mandal dkk., 2007)

\begin{tabular}{lc}
\hline Pelarut & Konstanta dielektrik \\
\hline Aseton & 20.7 \\
Asetonitril & 37.5 \\
Etanol & 24.3 \\
Heksan & 1.89 \\
Metanol & 32.6 \\
2-propanol & 19.9 \\
Air & 78.3 \\
\hline
\end{tabular}

Pada tabel 2 di atas dapat dilihat bahwa kemampuan methanol dan etanol dalam menyerap energy lebih redah daripada air karena nilai konstanta dielektrik juga lebih rendah. Heksan yang dan pelarut lain yang bersifat kurang polar hanya akan melewatkan gelombang panas tidak dapat menghasilkan panas untuk itu jika ekstraksi menggunakan heksana maka harus dikombinasikan dengan pelarut yang lebih polar seperti etanol ataupun methanol.

Selain jenis pelarut itu sendiri yang dapat dilihat dari nilai konstanta dielektriknya, maka volume pelarut juga mempengaruhi hasil optimal dari proses ekstraksi berbantu gelombang mikro. Volume pelarut pada umumnya cukup digunakan jika senyawa yang akan diekstrak terendam seluruhnnya. Jumlah volume pelarut jika lebih banyak pastinya dapat meningkatkan perolehan ekstrak akan tetapi berbeda dengan ekstraksi berbantu gelombang mikro yang akan menghasilkan ekstrak lebih rendah jika volume pelarut yang digunakan semakin banyak (Mandal dkk., 2007).

Daya merupakan faktor yang tidak bisa lepas dari waktu. Pada umumnya waktu semakin waktu meningkat maka daya yang digunakan juga meningkat. Daya yang optimal pada proses ekstraksi berbantu gelombang mikro yang baik pada 30 higga 150 watt. 
Jika daya berada antara kisaran 400 hingga 1200 watt proses ekstraksi tidak akan optimal, karena pada kondisi ini radiasi gelombang elektromagnetik tidak berpengaruh terhadap rendemen ekstrak. Pemilihan variasi daya dan waktu yang baik dapat mengurangi degradasi termal.

\section{METODOLOGI}

\subsection{Bahan}

Bahan yang digunakan dalam penelitian ini antara lain lidah buaya, etanol, metano, $\mathrm{n}$ heksan dan aquades.

\subsection{Alat}

Alat yang diperlukan dalam penelitian antara lain: alat gelas, ekstraktor gelombang mikro, spektrofotometer uv vis

\subsection{Prosedur Kerja}

Sebanyak $20 \mathrm{~g}$ daging lidah buaya ditambahkan kedalam $200 \mathrm{ml}$ pelarut 2 $\mathrm{mol} / \mathrm{L}$ (atau sesuai variabel). Campuran diekstrak selama 15 menit pada daya $10 \%$ daya maksimal (atau sesuai variabel). Setelah selesai larutan dibiarkan mengendap selama 60 menit kemudian dipisahkan dengan penyaring. Filtrat ditambah dengan aquades hingga mengkristal setelah larutan dibiarkan selama 1 jam. Hasil ekstraksi yang berbentuk endapan dipisahkan selanjutnya dioven kemudian diukur berat rendemennya.

\section{HASIL DAN PEMBAHASAN}

Pada penelitian ini digunakan gelombang mikro untuk mengekstrak senyawa antioksidan dari lidah buaya. Gelombang mikro berasal dari pembangkitan ultrason secara lokal dari kavitasi yang mengelilingi senyawa yang akan diekstraksi. Pada proses ekstraksi lidah buaya berbantu gelombang mikro ini pemanasan dapat terjadi. Pengaruh yang dihasilkan ada dua macam yaitu dinding sel lidah buaya menjadi terbuka sehingga membebaskan kandungan antioksidan. Peningkatan difusi ekstrak terjadi seiring pelewatan radiasi gelombang elektromagnetik. Energi kinetik dilewatkan ke seluruh bagian cairan diikuti dengan munculnya gelembung kavitasi pada dinding atau permukaan sehingga meningkatkan transfer massa antara permukaan padat-cair. Efek mekanik yang ditimbulkan adalah meningkatkan penetrasi dari cairan menuju dinding membrane sel, mendukung pelepasan komponen sel dan menunjukan transfer massa.

Pemilihan pelarut merupakan salah satu faktor yang penting dalam proses ekstraksi antioksidan dari lidah buaya sebagai bahan dasar menggunakan metode ekstraksi berbantu gelombang mikro menggunakan n-heksane digunakan sebagai pelarut dalam proses ekstraksi zat antioksidan dalam aloe vera karena merupakan pelarut yang bersifat polar. Akan tetapi kemampuan n-heksane mengekstrak senyawa yang memiliki kepolaran rendah hingga tinggi perlu dibantu oleh metanol yang mempunyai koefisien dielektrik lebih rendah. Hasil ekstraksi dipekatkan dengan cara dipanaskan perlahan pada temperatur $70-80^{\circ} \mathrm{C}$ untuk menghindari degradasi. Hasil ekstraksi antioksidan yang dihasilkan dapat dilihat pada Gambar 1.

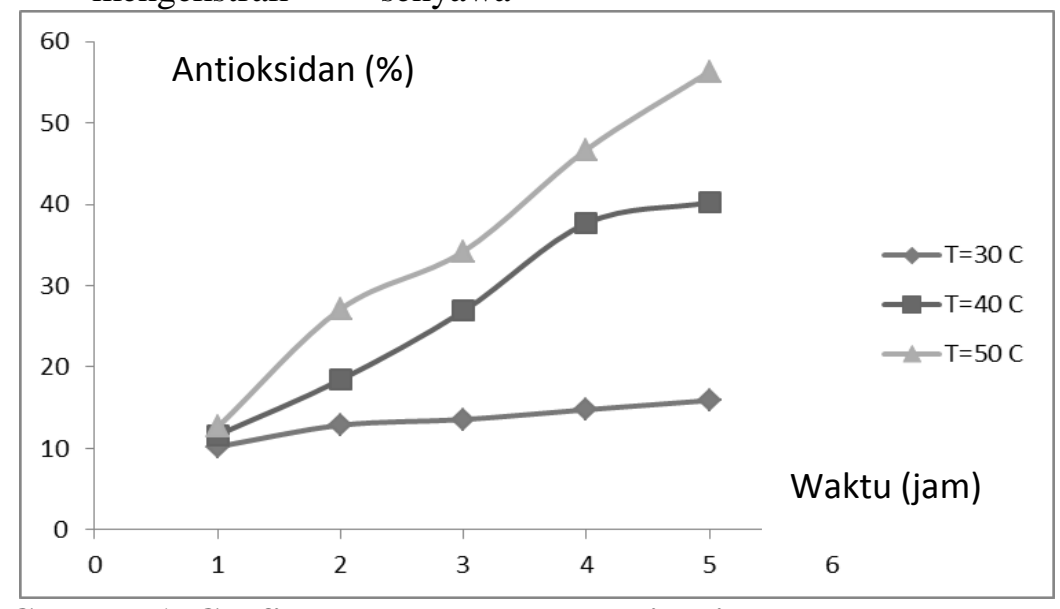

Gambar 1. Grafik hubungan kadar antioksidan, waktu dan suhu 
Pada gambar 1 diperoleh antioksidan optimum sebesar $56,29 \%$ pada suhu $50^{\circ} \mathrm{C}$ dan waktu ekstraksi 5 jam. Pada suhu $30^{\circ} \mathrm{C}$ diperoleh antioksidan aloe vera terbesar $15,90 \%$ dan pada suhu $40^{\circ} \mathrm{C}$ diperoleh antioksidan paling tinggi sebesar $40,22 \%$. Semakin lama waktu ekstraksi jumlah antioksidan yang dihasilkan dari aloe vera semakin besar karena pada durasi awal pemaparan gelombang mikro akan meningkatkan hidrasi material aloe vera dan mempunyai efek pada kavitasi. Efek kavitasi

menyebabkan n-heksane dan metanol sebagai pelarut berdifusi ke dalam material aloe vera. Pada kondisi tersebut kemampuan pelarut untuk mengekstrak antioksidan semakin meningkat (Ladda, 2010).

Pengaruh variasi konsentrasi n-heksane terhadap kadar antioksidan dapat dilihat pada Gambar 2.

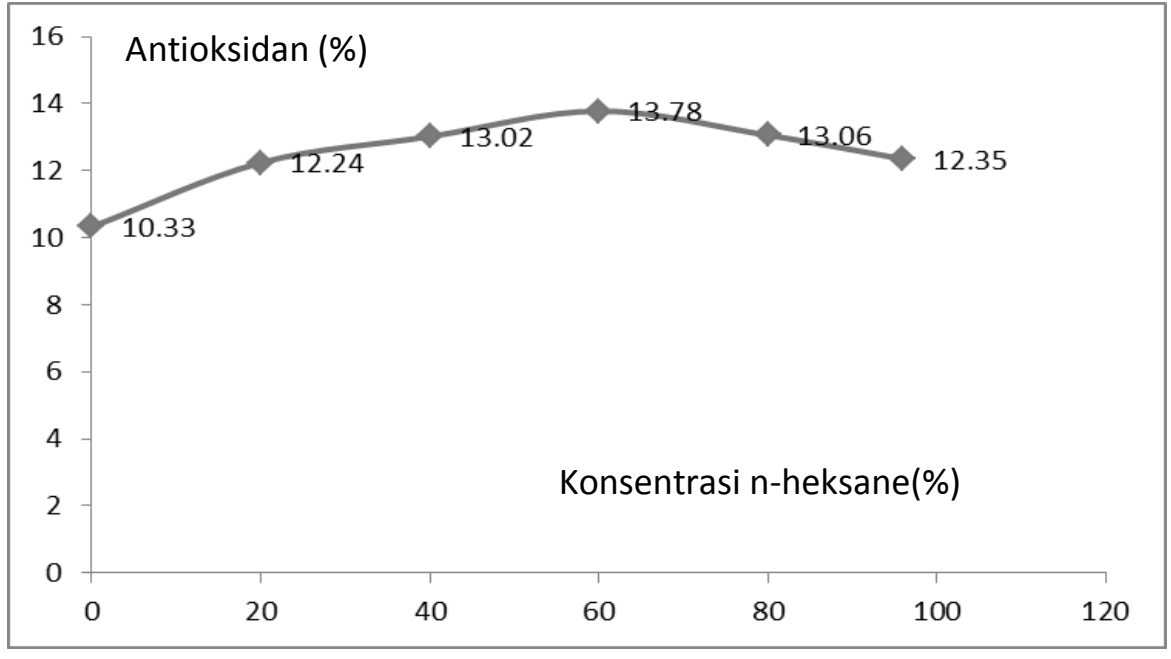

Gambar 2. Hubungan antara konsentrasi n-heksane dengan kadar antioksidan

Pada gambar 2 memperlihatkan bahwa antioksidan dari aloe vera paling besar dihasilkan pada konsentrasi pelarut n-heksan 60 $\%$ sebesar $13,78 \%$. Metanol pada proses ekstraksi menggunakan gelombang mikro bertindak sebagai rambatan gelombang. Gelombang mikro akan menginduksi terjadinya fenomena kavitasi yang mempunyai peran penting pada ekstraksi antioksidan. Ekstraksi antioksidan ini juga dipengaruhi oleh viskositas pelarut metanol dalam mempengaruhi pembentukan kavitasi. Viskositas berbanding lurus dengan peningkatan konsentrasi metanol. Viskositas akan menghambat pembentukan kavitasi sehingga dapat dilihat pada kosentrasi $80 \%$ dan $96 \%$ terjadi penurunan hasil antioksidan yang diperoleh yaitu dari $13,78 \%$ menjadi $13,06 \%$ dan $12,35 \%$.

\section{KESIMPULAN}

Penggunaan pelarut n-heksane akan efektif jika ditambahkan pelarut methanol yang lebih polar. Hasil optimum Antioksidan dari aloe vera sebesar $56,29 \%$ pada suhu $50^{\circ} \mathrm{C}$ dan waktu ekstraksi 5 jam. Antioksidan dari aloe vera juga dihasilkan optimum jika konsentrasi pelarut n-heksan $60 \%$ sebesar 13,78\%.

\section{DAFTAR PUSTAKA}

Hernani, Raharjo, M, (2005), Tanaman berkhasiat Antioksidan, Jakarta. Penebar Swadya.

Kumoro, A.C., Hasan, M., (2007), Supercritical $\mathrm{CO} 2$ Extraction of Andrographolide from Andrographis paniculata: Effect of the Solvent Flow Rate, Pressure, and Temperaturell, China Journal of Chemical Engineering, Vol $15,877-883$.

Ladda, K.S., Gavit, R.S., Bhandare, R.R., (2010), Effect of Enzyme on Extraction of Andrographolide from Andrographis paniculata neesll, International Journal of Pharma and Bioscience, Vol 1, 1-7.

Mandal, V., Mohan, Y., Hemalatha, S., (2007), Microwave Assisted Extraction-An Innovative and Promissing Extraction Tool for Medicinal Plant Research, Pharmacognosy Reviews, 1(1):18. 